(RESEARCH ARTICLE)

\title{
Effect of optimization conditions on submerged fermentation of corn bran for the production of xylanase enzyme
}

\author{
Afangide Christopher Stephen ${ }^{1}{ }^{*}$, Orukotan Abimbola Adeniyi ${ }^{1}$ and Jamilu Hadiza ${ }^{2}$ \\ ${ }^{1}$ Department of Microbiology, Faculty of Science, Kaduna State University, Kaduna, Nigeria. \\ ${ }^{2}$ Department of Applied Biology, Faculty of Science, Kaduna Polytechnic, Kaduna, Nigeria.
}

Publication history: Received on 25 January 2020; revised on 01 February 2020; accepted on 04 February 2020

Article DOI: https://doi.org/10.30574/wjarr.2020.5.2.0020

\begin{abstract}
UV- rays were used as mutagens on wild type of Aspergillus niger for enhanced production of Enzyme - Xylanase. The xylanase producing species were isolated from soil and exposed to UV rays at various timings of $20 \mathrm{mins}, 40 \mathrm{mins}, 60$ mins, 80 mins, 100 mins and 120 mins. The mutants AN20 - AN100 showed 19.96, 21.22, 22.66, 27.88, and 37.77 \% increase in activities of cellular xylanase respectively in comparison with the parental strain $(0.556 \pm 0.06)$. Mutant AN100 exposed to UV ray for 100 minutes was therefore selected as the best producer of xylanase after 7 days of fermentation using Corn bran as a substrate. As seen in the result, increase in time of exposure resulted to a decrease in cellular xylanase production. Optimization of xylanase production was carried out and the result obtained revealed that mutant AN100 showed best xylanase activity when cultivated at $\mathrm{P}^{\mathrm{H}} 5,30{ }^{\circ} \mathrm{C}$ and without addition of any other Carbon or Nitrogen source. Aspergillus niger is a good producer of xylanase under the conditions determined in this assay
\end{abstract}

Keywords: Submerged fermentation; Xylanase; Optimization; Aspergillus niger

\section{Introduction}

Xylanases are enzymes that degrade xylan, a hemicellulose found in plant cell walls into xylose. Hemicellulose is the second abundant renewable biomass in nature. Xylan is the major hemicellulose component and approximately accounts for 20-25\% of plant cell wall dry weights [1]. They are very important class of enzymes used in paper and pulp industry. The basic structure of xylan is B-D-1, 4-linked xylopyranosyl residue with a few relatively short side chains. The heterogeneity of xylan led to a diversity of xylan-degrading enzymes.

Hitherto, the removal of lignin from paper and pulp was by chlorine and its compounds which have caused serious problem to health and environment. However, delignification by xylanase is an alternative approach, which is environmentally friendly [2].

Xylanases are of considerable interest because of their applications in bleaching of pulp in the paper industry, food processing, bio-conversion of biomass wastes to fermentable sugars and clarification of fruit juices [2]. They also have application in improvement, nutrient digestibility in animal diets and in the production of 3-xylooligosaccharides and xylose.

Apart from its use in the pulp and paper industry, xylanases are also used as food additives to poultry, in wheat flour for improving dough handling and quality of baked products, for the extraction of coffee, plant oils, and starch, in the improvement of nutritional properties of agricultural silage and grain feed, and in combination with pectinase and cellulase for clarification of fruit juices and degumming of plant fiber sources such as flax, hemp, jute, and ramie.

\footnotetext{
${ }^{*}$ Corresponding author

E-mail address: chrisafangide@gmail.com
} 
Commercial applications for xylanase include the chlorine-free bleaching of wood pulp prior to the paper making process, and the increased digestibility of silage (in this aspect, it is also used for fermentative composting)

Large quantities of hemicellulosic wastes can be generated through forestry, agricultural practices and industrial processes, particularly from agro -allied industries such as breweries, pulp and paper, textile and timber industries. These wastes generally accumulate in the environment thereby causing pollution and other environmental hazards. Most of the wastes are disposed by burning, a practice considered as major factor in global warming. However the plant biomass regarded as "wastes" are biodegradable and can be converted into valuable products such as biofuels, chemicals, cheap energy sources for fermentation, improved animal feeds, human nutrients and production of enzymes such as xylanases.

A Variety of microorganisms, including bacteria, yeasts and filamentous fungi, have been reported to produce xylanases and over the years, a number of organisms of the genus Penicilium, Trichoderma, Pleurotus, Aspergillus, Streptomyces and Bacillus have been manipulated for xylanase biosynthesis [3,4]. However, Aspergillus niger has been described as the most potent organism for xylanase production [2]

In this study effort was made to improve xylanase production from mutagenization of $A$. niger as a means of obtaining isolates with high yields of xylanase. The mutants were compared with the parental strain for the production of xylanase using corn bran as a substrate.

\section{Material and methods}

\subsection{Collection of samples}

Corn bran was collected from a local milling house located in Gonin-gora market in Kaduna metropolis, while Soil sample was collected from one inch below the soil surface in sterile bag from the waste dump site behind Federal Government College - Kaduna state in Nigeria. Samples were transferred into a sterile polyethylene bag and dispatched to the Microbiology Laboratory, Kaduna State University, Nigeria and kept at ambient temperature till use.

\subsection{Isolation of fungi for xylanase production}

One milliliter $(1 \mathrm{ml})$ of the serially diluted soil sample was poured into sterile petri dishes containing Potato Dextrose Agar (PDA) medium. Streptomycin ( $0.05 \mathrm{~g})$ was added to the molten PDA medium in the petri dishes and incubated at $30 \pm 1^{\circ} \mathrm{C}$ for 5 days for the isolation of Aspergillus spp. Preliminary identification of the fungi was done based on their morphological characteristics. The dominant isolates of Aspergillus niger was sub-cultured in PDA medium. The isolated Aspergillus spp was purified by restreaking on the medium and the pure cultures were maintained on PDA slants stored at $4{ }^{\circ} \mathrm{C}$ in the refrigerator.

The isolated fungal culture was identified as Aspergillus niger based on colonial morphological and microscopic characteristics and these values matched with values in standard reference book compendium of soil fungi [5].

\subsection{Screening of $A$. niger isolates for xylanase production}

Screening for the production of xylanase was performed on Potato Dextrose agar (PDA) containing 0.1\% (w/v) of commercial xylan. Positive xylanolytic isolates were detected based on the clear zones of hydrolysis of the xylan [6]. The potential isolates were sub cultured and maintained on PDA slants. The slants were then stored at 40c prior to use.

\subsection{Modification of $\boldsymbol{A}$. niger isolates by $\mathrm{UV}$ treatment for enhanced xylanase production}

Various serial dilutions of fungal suspension were prepared and dilution $10^{-2}, 10^{-3}$ and $10^{-4}$ were distributed into sterilized petri plates $(2 \mathrm{ml}$ in each plate). These were exposed to UV radiations for varying time periods ranging from 20 to 120 minutes in UV chamber keeping the distance of UV source at $15 \mathrm{~cm}$. After UV radiation they were kept in dark for stabilization of thymine thymine (T-T) dimmers. Parent type and UV treated fungal spore suspensions of $0.1 \mathrm{ml}$ was inoculated into $25 \mathrm{ml}$ petri plate containing potato dextrose agar medium. Then developed fungal strains whose survival rate was less than $1 \%$ were screened on PDA containing $0.1 \%(\mathrm{w} / \mathrm{v})$ of commercial xylan for hyper- xylanase activity. 


\subsection{Xylanase production using selected mutants and parent $A$. niger on corn bran}

\subsubsection{Inoculum preparation for xylanase production}

Spores were harvested by flooding the plates with sterile distilled water containing $0.05 \%$ Tween 80 as a wetting agent, after which spores were scraped from the surface of the colonies with a sterile spatula. The resulting suspension was shaken in a $100 \mathrm{ml}$ Erlenmeyer flask to break up the spore chains. The concentrations of spores was determined using a hemocytometer, after which the suspension was further diluted in sterile Tween 80 solution to achieve the desired concentration $\left(10^{7}\right.$ spore per $\left.\mathrm{ml}\right)$.

\subsubsection{Substrate preparation and culture condition}

The corn bran was pounded into coarse particle sizes, washed exhaustively with warm water, then air dried to eliminate moisture and make it susceptible to ball milling [7]. Milled sample was then sieved to particle size of 850u to be used for all experimentation. The basal medium for enzyme production was prepared by introducing corn bran (10g) into $100 \mathrm{ml}$ Erlenmeyer flask with the nutritive solution containing in each liter; $\mathrm{KH}_{2} \mathrm{PO}_{4}(2.0 \mathrm{~g})$, $\left(\mathrm{NH}_{4}\right)_{2} \mathrm{SO}_{4}(1.4 \mathrm{~g}), \mathrm{MgSO}_{4}$ $7 \mathrm{H}_{2} \mathrm{O}(0.3 \mathrm{~g}), \mathrm{CaCl}_{2}(0.3 \mathrm{~g})$, Urea (0.3 g), Tween-80(1 ml), $\mathrm{FeSO}_{4} .7 \mathrm{H}_{2} \mathrm{O}(5.0 \mathrm{mg}), \mathrm{MnSO}_{4} \cdot \mathrm{H}_{2} \mathrm{O}(1.6 \mathrm{mg}), \mathrm{ZnSO}_{4} .7 \mathrm{H}_{2} 0(1.4 \mathrm{mg})$, $\mathrm{CoCl}_{2}(2.0 \mathrm{mg})$.

The $\mathrm{pH}$ was adjusted to 5.0. [8]. Cultivation mass made in $100 \mathrm{ml}$ Erlenmeyer flasks, each containing $50 \mathrm{ml}$ of sterilized media. One milliliter of spore suspension obtained from 7day mutant cultures was used for inoculation. Cultivation was performed at 30 degree Celsius on a rotary shaker (180rpm). The culture was harvested on the seventh day of growth by filtration through Whiteman filter paper and then centrifuged. The clear supernatant was used for enzyme assay.

\subsection{Enzyme assay of xylanase}

Xylanase activity in the culture filtrate was determined from the amount of the reducing sugars formed in terms of xylose according to the method of [8]. Half milliliter of the culture filtrate was added to $0.5 \mathrm{ml}$ of $10 \%$ (w/v) xylan in $0.05 \mathrm{M}$ Phosphate buffer ( $\mathrm{pH}$ 5.0). The reaction mixture was incubated at $45{ }^{\circ} \mathrm{C}$ for 30 minutes. The release of the reducing sugars was determined by the dinitrosalicylic acid method according to [9]. One unit (U) of xylanase activity was defined as the amount of enzyme liberating one mole of reducing sugars as xylose per minute. The activity of Xylanase enzyme was determined as $\mathrm{IU} / \mathrm{ml}$. Enzyme activity was calculated from the amount of reducing sugar produced in 30 minutes, using the formula.

$$
\begin{aligned}
& \text { Amount of reducing sugar } \times 1000 \times 1
\end{aligned}
$$

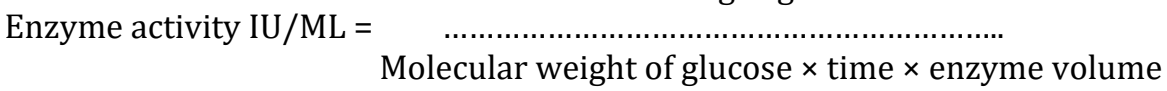

\subsection{Optimization studies for enzyme production}

Various physiochemical factors affecting enzyme production such as source of carbon or sugar fermentation, source of Nitrogen, Temperature condition and $\mathrm{pH}$ condition were optimized for maximum yield [8].

\subsubsection{Effect of additional carbon sources}

Different carbon sources were tested for their ability to enhance xylanase production, they are (Xylose, Fructose, Maltose, Mannitol, Sucrose, Galactose, Lactose and Glucose) which were added to the fermentation medium in ratio 1 $\%(\mathrm{w} / \mathrm{v})$ separately and incubated for 7 days at $30^{\circ} \mathrm{C}$

\subsubsection{Effect of additional nitrogen sources}

Nitrogen sources (organic and inorganic) were also tested for the ability to enhance Xylanase production. These include Yeast extract, Sodium nitrate $\left(\mathrm{Na}_{2} \mathrm{NO}_{3}\right)$, Ammonium Sulphate $\left(\mathrm{NH}_{4} \mathrm{SO}_{4}\right)$, and Urea which were added to the fermentation medium in ratio $0.5 \%(\mathrm{w} / \mathrm{v})$ separately and incubated for 7 days at $30^{\circ} \mathrm{C}$

\subsubsection{Effect of fermentation temperature}

In order to determine the optimum temperature for Xylanase production, the culture medium was properly inoculated and incubated for 7 days at various temperature $20,25,30,35$, and $40{ }^{\circ} \mathrm{C}$. 


\subsubsection{Effect of fermentation $p H$}

In order to determine the optimum $\mathrm{pH}$ for the production of xylanase, the fermentation broth was adjusted to various $\mathrm{pH}$ such as 4, 4.5, 5.5, 6 and 6.5. After 7 days fermentation, enzyme activity was determined and compared with the control.

\section{Results and discussion}

\subsection{Spectroscopic determination of xylanase activity of $\boldsymbol{A}$. niger}

Table 1 Effect of time of UV-induce mutant strain of A. niger on xylanase production from SmF of corn bran

\begin{tabular}{lll}
\hline Code of organisms & Time of exposure (minutes) & Enzyme activities (iu/ml) \\
\hline WT & 0 & $0.556 \pm 0.06 \mathrm{~b}$ \\
AN20 & 20 & $0.667 \pm 0.04 \mathrm{c}$ \\
AN40 & 40 & $0.674 \pm 0.04 \mathrm{c}$ \\
AN60 & 60 & $0.682 \pm 0.03 \mathrm{c}$ \\
AN80 & 80 & $0.711 \pm 0.06 \mathrm{~d}$ \\
AN100 & 100 & $0.766 \pm 0.01 \mathrm{~d}$ \\
AN120 & 120 & $0.444 \pm 0.04 \mathrm{a}$ \\
\hline
\end{tabular}

Code: $\mathrm{WT}=$ parent strain of Aspergillus niger, AN20 - AN100 = Mutant strains of Aspergillus niger. Values are mean \pm SEM of 3 determinations. Values along the same column with different superscripts are significantly different $(\mathrm{p}<0.05)$.

Modification of Aspergillus niger by UV treatment had a positive effect on the production of xylanase. The duration of exposure was directly proportional to the enzyme activity of the mutants. The enzyme production from the mutant strain increased significantly with increased time of UV exposure from 20 minutes to 100 minutes after which the production declined significantly at 120 minutes of UV exposure. This result revealed that mutant exposed to 120 minutes exhibited the least enzyme activity. Exactly $37.77 \%$ increase in enzyme activity was recorded when mutant AN100 (exposed to 100minutes) was used, in comparison with the parent strain. This result is in agreement with that of [10] who used UV treatment on Aspergillus niger to obtain an increase of $82.31 \%$ in glucose oxidase production. However, [11] and [12] reported maximum enzyme activity after 45minutes and 25minutes of UV irradiation respectively.

\subsection{Optimization condition for sugar fermentation}

Table 2 Effect of different carbon sources on xylanase production from SmF of corn bran

\begin{tabular}{ll}
\hline Carbon sources & Enzyme activity $(\mathbf{i u} / \mathbf{m l})$ \\
\hline Xylose & $0.088 \pm 0.01 \mathrm{f}$ \\
Fructose & $0.040 \pm 0.00 \mathrm{~d}$ \\
Maltose & $0.007 \pm 0.00 \mathrm{a}$ \\
Mannitol & $0.074 \pm 0.01 \mathrm{e}$ \\
Sucrose & $0.030 \pm 0.00 \mathrm{c}$ \\
Galactose & $0.070 \pm 0.01 \mathrm{e}$ \\
Lactose & $0.015 \pm 0.01 \mathrm{~b}$ \\
Glucose & $0.082 \pm 0.02 \mathrm{f}$
\end{tabular}

Values are mean \pm SEM of 3 determinations. Values along the same column with different superscripts are significantly different (p $<0.05$ )

The mutant strain of Aspergillus niger (AN100), used in this study showed different enzyme activity with additional sugars to the fermentation broth. The sugar consists of Xylose, Fructose, Maltose, Mannitol, Sucrose, Galactose, Lactose and Glucose (Table 2). The result shows that Xylose exhibited the best enzyme activity of $0.088 \mathrm{iu} / \mathrm{ml}$ while Maltose had the least enzyme activity of $0.007 \mathrm{iu} / \mathrm{ml}$. However, an inhibition of enzyme activity was observed with additional 
carbon sources. This result disagrees with the findings of [6] who reported maximum enzyme activity (25.40u/g) with supplementation of Xylose in solid state fermentation of Palm kernel cake using Aspergillus niger. The result however corroborates the results obtained by [13] who attributed such inhibitory effect to catabolic repression process. The findings of [8] also showed inhibitory actions of fermentative sugars on xylanase production while detecting an increase in enzyme activity with the supplementation of culture with 3-5\% of lignocellulosic materials.

\subsection{Enzyme assay for nitrogen optimization}

Table 3 Effect of different Nitrogen sources on xylanase Production from SmF of Corn Bran

\begin{tabular}{ll}
\hline Nitrogen sources & Enzyme activity (iu/ml) \\
\hline Yeast extract & $0.63 \pm 0.02 \mathrm{~b}$ \\
Na2NO3 & $0.64 \pm 0.01 \mathrm{~b}$ \\
NH4SO4 & $0.59 \pm 0.04 \mathrm{a}$ \\
Urea & $0.65 \pm 0.01 \mathrm{~b}$ \\
Control & $0.766 \pm 0.01$ \\
\hline
\end{tabular}

Values are mean \pm SEM of 3 determinations. Values along the same column with different superscripts are significantly different $(p<0.05)$.

The highest enzyme activity was observed in urea with $0.65 \mathrm{iu} / \mathrm{ml}$, followed by $\mathrm{Na}_{2} \mathrm{NO}_{3}$ with $0.64 \mathrm{iu} / \mathrm{ml}$, yeast extracts with $0.63 \mathrm{iu} / \mathrm{ml}$ and $\mathrm{NH}_{4} \mathrm{SO}_{4}$ with $0.59 \mathrm{iu} / \mathrm{ml}$ respectively (Table 3). This showed that organic source of nitrogen was the best source of nitrogen for xylanase production. Effectiveness of inorganic nitrogen compounds on Xylanase production has also been reported by [6]. However, the result in table 1 indicates that Corn bran alone is more suitable for xylanase production. The mutant $A$. niger (AN100) used in this study reaches the maximum xylanase activity (0.766 $\mathrm{iu} / \mathrm{ml}$ ) in the absence of additive nitrogen to the main medium. The richness of natural Corn bran with protein, Carbohydrate and Fiber as reported by [17] may be enough to stimulate growth and enhance xylanase production. This result disagrees with the finding of [14] who reported that $A$. niger requires $\mathrm{Na}_{2} \mathrm{NO}_{3}$ to enhance xylanase production. Some other fungi such as T. viride as reported by [2] require ammonium $\left(\mathrm{HN}_{4}\right)$ residue to improve xylanase production.

\subsection{Optimization condition for temperature}

Table 4 Effect of temperature on xylanase production from SmF of corn bran using mutant strain of $A$. niger.

\begin{tabular}{cc}
\hline Temperature (0C) & Enzyme Activities (iu/ml) \\
\hline 20 & $0.059 \pm 0.01 \mathrm{~b}$ \\
25 & $0.089 \pm 0.01 \mathrm{c}$ \\
30 & $0.766 \pm 0.01 \mathrm{e} \quad$ control \\
35 & $0.415 \pm 0.09 \mathrm{~d}$ \\
40 & $0.037 \pm 0.01 \mathrm{a}$ \\
\hline
\end{tabular}

Values are mean \pm SEM of 3 determinations. Values along the same column with different superscripts are significantly different $(p<0.05)$.

The mutant strain of Aspergillus niger (AN100) used in this study showed that the optimum incubation temperature for production of xylanase enzyme was $30^{\circ} \mathrm{C}$ with enzyme activity of $0.766 \mathrm{iu} / \mathrm{ml}$. Xylanase production was extremely low at $40^{\circ} \mathrm{C}$ (Table 4). The result obtained is similar to those obtained by other authors who established that the best temperature range for xylanase activity is between $20^{\circ} \mathrm{C}$ to $30^{\circ} \mathrm{C}$ [13 15 and 16 ]. At a lower temperature of $20^{\circ} \mathrm{C}$, a lower enzyme activity of $0.059 \mathrm{iu} / \mathrm{ml}$ was recorded. Lower temperature decreases enzyme production because it is unsuitable for mold growth and as a result, lowers enzyme production while higher temperature limits oxygen concentration and leads to reduction in media water content by vaporization thereby affecting cell growth and consequently decreases enzyme activity. For A. niger (AN100), the optimum temperature for xylanase production was similar to the temperature of natural habitat of the parent strain where it was initially isolated. This corroborates the result of [6] who showed that the highest xylanase activity was obtained at temperature that was optimum for growth of the fungus in solid state fermentation. 


\subsection{Enzyme assay for $\mathrm{pH}$ optimization}

Table 5 Effect of pH on xylanase Production from SmF of Corn Bran using mutant strain of $A$. niger

\begin{tabular}{ll}
\hline $\mathbf{p H}$ & Enzyme activities (iu/ml) \\
\hline 4 & $0.563 \pm 0.10 \mathrm{~b}$ \\
4.5 & $0.526 \pm 0.16 \mathrm{~b}$ \\
5 & $0.776 \pm 0.01 \mathrm{~b}$ \\
5.5 & $0.578 \pm 0.09 \mathrm{~b}$ \\
6 & $0.563 \pm 0.08 \mathrm{~b}$ \\
6.5 & $0.444 \pm 0.09 \mathrm{~b}$ \\
\hline
\end{tabular}

Values are mean \pm SEM of 3 determinations. Values along the same column with different superscripts are significantly different $(p<0.05)$.

The highest enzyme activity in this study $(0.766 \mathrm{iu} / \mathrm{ml})$ was obtained at $\mathrm{pH} 5$ while the least activity of $0.444 \mathrm{iu} / \mathrm{ml}$ was observed at pH 6.5, using the mutant strain of $A$. niger (AN100). This result disagrees with the findings of [14] who reported that the best xylanase production $(1.48 \mathrm{u} / \mathrm{ml})$ was at $\mathrm{pH} 6$ when $A$. niger was used in solid state fermentation of wheat straw. Fluctuation in enzyme production was observed as the pH increases (Table 5). The low enzyme activity at $\mathrm{pH} 4$ may partially be due to inactivation of the enzyme at this $\mathrm{pH}$ rather than inhibition of enzyme biosynthesis.

\section{Conclusion}

From this research work Aspergillus niger was isolated from soil. Modification of this wild type of $A$. niger, using UVrays at 100 minutes resulted to a mutant with a higher ability to produced xylanase enzyme in a submerged fermentation of Corn bran. Optimization of xylanase production indicated that the mutant showed best xylanase activity when cultivated at $\mathrm{P}^{\mathrm{H}} 5,30^{\circ} \mathrm{C}$ and without addition of any other carbon or nitrogen source. Mutation of Aspergillus niger, using UV treatment enhances production of xylanase enzyme under the conditions determined in this assay.

\section{Compliance with ethical standards}

\section{Acknowledgments}

The authors wish to acknowledge the unending and unquantifiable assistance rendered by Mal. Mohammed Sani of Microbiology department and Mr. Austin Marcus of Biochemistry department, Kaduna State University. Nigeria.

\section{Disclosure of conflict of interest}

Authors have declared that no competing interests exist.

\section{References}

[1] Jiang Z, Q Cong, Q Yan, N Kumar and X Du. (2010) Characterization of Thermostable xylanase from Chaetomium sp and its application in Chinese steamed bread. Food Chemistry, 120, 457-462.

[2] Soliman M, Hoda, Abdel-Dayem, Sherief A, Arafat B and El-Tanash (2012). Production of xylanase by A. niger and Trichoderma viride using some agriculture residues. International Journal of Agricultural Research, 10, 3923.

[3] Fadel M and Fouda M. (1994). Physiological studies on xylanase production by Penicillium funiculosum on some agricultural wastes. Zentralblatt fur Mikrobiologi, 148, 304-312.

[4] Zulfiqar, Ahmad, Masood, Sadiq B, Muhammad, Tahir N and Muhammed Y. (2013). Optimization of cultural conditions for xylanase biosynthesis by Aspergillus niger using sugarcane bagasse. Pakistan Journal of Food Sciences, 23(2), 94-99.

[5] Domsch KH and Gams W. (1980). Compendium of soil fungi. Trevte-Teidi Anderson (Eds.), Academic Press, London. 
[6] Pang PK and Ibrahim CO. (2005). Xylanase production by a local fungal isolate, A. niger USM Al.1 via solid state fermentation using palm kernel Cake (PKC) as substrate. Songklanakarin Journal of Science and Technology, 27(2), 325-336.

[7] Damisa D, Ameh J and Umoh V. (2008). The effect of changes in manganese Concentrations on cellulose yield from bagasse fermented with mutagenized strain of A. nigerAH3. International Journal of Biological and Chemical Sciences, 2(3), 368-372.

[8] Karunakaran S, Saravanan A, Dhanasekaran S, Senbagam D and Senthil kumar B. (2014). Xylanase Production from Aspergillus niger. International Journal of Chemistry Technology Research, 6(9), 4207-4211.

[9] Miller GL. (1959). Use of dinitrosalicylic acid reagent for determination of reducing sugar. Analytical chemistry, 31, 426-428.

[10] Muhammad R and Tahir M. (2008). Enhanced production of Glucose oxidase from UV- mutants of Aspergillus niger. African Journal of Biotechnology, 8(2), 288-290.

[11] Ikran-ul-H, A Khan, Butt WA, Ali S and Qadeer MA. (2002). Effect of carbon and nitrogen sources on xylanase production by mutant strain of Aspergillus niger GCBMX-45. Journal of Biological Sciences, 2(2), 143-144.

[12] Ikran-ul-H, Shaida J and Hamad A. (2002). Production of Amyloglucosidase by UV irradiated Strain of Aspergillus niger. Asian network of Scientific Information, 1(1), 34-39.

[13] Simoes MLG and Tauk-Tornisielo SM. (2006). Optimization of Xylanase biosynthesis by Aspergillulus jopanicus. African journal of biotechnology, 5(11), 1135-1141.

[14] Kanimozhi K and Nagalakshmi pk. (2014). Xylanase production from Aspergillus niger by solid state fermentation using agricultural wastes as substrate. International Journal of current microbiology and Applied Science, 3(3), 437-446.

[15] Haq I, Tasneem M, Raana K, Khan A, Mukhtar H and Javed M. (2004). Optimization of Cultural conditions for the production of Xylanase from chemically mutated Stain of Aspergillus niger GCBCX-20. International Journal of Agriculture and Biology, 6, 1115- 1118.

[16] Shah AR and Madamwar. (2005). Xylanase production by a newly isolated Aspergillus foetidus strain and its characterization. Process Biochemistry, 40, 1763-1771.

[17] Afangide CS, Orukotan AA and Ado SA. (2018). Proximate composition of Corn Bran as a potential substrate for the production of xylanase using Aspergillus niger. Journal of Advances in Microbiology, 12(3), 1-4.

\section{How to cite this article}

Afangide CS, Orukotan AA and Jamilu H. (2020). Effect of optimization conditions on submerged fermentation of corn bran for the production of xylanase enzyme. World Journal of Advanced Research and Reviews, 5(2), 19-25. 